From a/topia to topia: towards a gendered right to the city for migrant volunteers in London

\begin{abstract}
The paper makes use of an un-orthodox Lefebvrian formulation of the 'right to the city' as it adds the gender dimension which was absent from Lefebvre's work. The lens of 'gendered right to the city' (Doderer, 2003; Fenster, 2005; Vacchelli, 2014) is used in order to understand the experiences of volunteers working in the women's community and voluntary sector in London. We look specifically at the role of migrant organisations both as places of co-option of migrant labour, as places that enable the integration of migrants and make their participation in the urban fabrics possible, and as places that are appropriated by migrant volunteers in London as a means of enacting active citizenship.

London's governance, policy discourses and practices seek to impose a top-down idea of civic participation. In this vision, the role of migrant groups and organisations can only be valued in the context of an active civil society, able to replace the vacuum left by the progressive erosion of the welfare state, leading to a crisis of social reproduction. Lefebvre's theoretical framework of 'space appropriation' serves as a way to explore these questions and we propose a further spatial reading which is specific to a gendered right to the city, i.e. the shift from a/topia (not having a space or being denied access to public spaces broadly conceived) to topia. We speculate on what this newly found space looks like and what is its potential for the subversion of top-down policy discourses on civic participation in the neoliberal city.
\end{abstract}

Keywords: social reproduction, migrant and refugee women, volunteering, space appropriation, integration, gendered right to the city. 


\section{From a/topia to topia: towards a gendered right to the city for migrant volunteers in London}

\section{Introduction}

This paper offers a reading of everyday citizenship enacted by migrant women who work in the voluntary and community sector in London, based on secondary research and our experience of conducting work in this field in the last few years (Vacchelli, 2015; Vacchelli et al., 2015) ${ }^{1}$. It interrogates bottom-up civic participation of migrant women volunteering in third sector organisations in the context of London's governance and discourses. Our reading is based on the work on urban space by the French scholar Henri Lefebvre. One of the central tenets of his theorisation on space is that (social) space is a (social) product. The Production of Space constitutes an attempt to combine all possible forms of space production and appropriation, from abstract to material ones, and represents Lefebvre's effort to theorise space by adopting a western European perspective situated in (and critical of) capitalism. David Harvey (2012), for instance, ascribes the 'Right to the city' to the kind of 'collective rights' opposed to individualistic rights and those based on private property. He does that in the frame of a renewed interest for the work on Henri Lefebvre and the emergence of social movements all over the world which claim a 'right to the city'. Harvey (2012) argues that the right to the city is much more than an individual access to a given set of urban resources: it is a right to change and re-invent the city as exemplified by the collective endeavours of activist groups trying to resist to neoliberal urbanisation processes.

The notion of the right to participation is strictly interconnected with appropriation as this is the right to make decisions concerning the production of urban space at different governmental scales and along different intensities of the privatised market and public provisions. Appropriation does not only refer to a natural occupation of goods in a Marxian sense but to an activity which is first and foremost spatial, taking place in space and with space. Appropriation is key to Lefebvre's theorisation given the fact that the right to the city is not grounded in normative notions of citizenship but rather in 'inhabitance', so that any urban dweller, strangers and citizens, can enjoy such a right. Appropriation therefore refers to the right of any city dwellers to use, live in, play, consume, work and occupy urban space as they deem appropriate (Purcell, 2002). We use Lefebvre's theoretical framework of 'space appropriation' as a starting point to propose a further spatial reading which is specific to a

\footnotetext{
${ }^{1}$ From a methodological point of view, this paper offers a policy analysis of one key document outlining migrants' organisations role in fostering integration in London. It also draws on a series of semi-structured interviews conducted with migrant and women's organisation managers as part of two recent small scale research projects. Due to the words limit for this paper there is no room to further expand on the empirical section (i.e. top-down and bottom-up definitions of civic participation) presented in the second part of this paper.
} 
gendered right to the city, i.e. the shift from a/topia (not having a space or being denied access to public spaces broadly conceived) to topia (having a space in the public domain). As it will become evident in the paper, this describes a specifically gendered process of space appropriation given the fact that women's work has often been traditionally linked to the private sphere and particularly to care work.

Social relations that are created by production forces, everyday social practices, different technologies and products of knowledge, as well as social structures and institutions need to take into account issues of difference including ethnic, gender and cultural diversity and the role these differences play in the active articulation of different forms of belonging (Fenster 2005). In particular, Yuval-Davis (2007) stresses the saliency of looking at the 'effects of intersecting social divisions on constructions of multi-layered citizenships (...)' (YuvalDavis, 2007: 7), multi-layered citizenship being defined by Yuval-Davis as a layering of positionalities in 'local, ethnic, national, state, cross- or trans-state and supra-state' locations (Yuval-Davis, 1999: 119). This intersectional perspective of a gendered citizenship, analysed in relation to identity and related emotions, notably allows her to further problematise politics of belonging (Yuval-Davis, 2007). We argue that an intersectional approach to gendering citizenship is necessary in order to understand migrant and refugee women experiences of bottom-up civic participation in London and aim at considering ethnicity and culture as further layers to our understanding of the right to the city.

The gendered right to the city is a call for radical restructuring of social, political and economic relations, both in the city and beyond. It cries for a shift of control away from state and capital and towards urban inhabitants. This paper aims at unpicking the question 'how would the right to the city challenge, complement or replace current rights or lack thereof?' It makes use of an un-orthodox Lefevrian formulation of the 'right to the city' as it adds the gender dimension which was absent from Lefebvre's original work. The first part of the article proposes a specifically gendered and feminist idea of the right to the city. The second part of the article discusses the top-down governance discourse on the role of migrant and refugee organisations in London. It highlights how migrant women working within the voluntary and community sector fall below the radar of public provisions and policy guidelines yet can be understood as an applied example of bottom-up space appropriation for a specifically gendered right to the city.

\section{Where is gender in the 'Right to the city'?}

The right to the city in a gendered perspective tends to be conceptualised in terms of safety in urban environments in relation to the dangers some urban spaces present to the personal safety of women. This includes public infrastructures and transportation which again links to the risk of violence in threatening public spaces. In addition, it addresses issues of proximity 
between housing, services and employment as the ways in which services are allocated pose mobility barriers in relation to social reproduction (Buckingham, 2010). Other perspectives on the specifically 'gendered' right to the city relate to breaking the dichotomy of public and private domains whereby 'urban spaces have been designed to value production and undervalue reproduction' (Buckingham, 2010, 62). Policy discourses on the right to the city have tended to emphasise the accessibility of services and have not paid enough attention to the lack of equal participation in the creation of urban spaces.

Feminist scholarship has looked at space in terms of spatial relations that are continually produced and contended within cities. For instance Kye Askins (2016) develops the idea of 'emotional citizenry' by looking at the role of emotions during intercultural encounters in the context of befriending services in the North East of England. She argues for an open and inclusive idea of citizenship where social justice for asylum seekers and refugees is not depoliticised. On the contrary, she contends that everyday and personal relations need to be re-politicised and understood as broader state politics taking place at the local scale of the neighbourhood.

Other scholars used the work of Henri Lefebvre 1968, 1991) to engage with daily practices that produce space (Doderer, 2003; Marston and Smith, 2001; Simonsen, 2005; Vacchelli, 2015) despite the fact that Lefebvre himself had neglected a specifically gendered perspective in his theorizations. However the fascination with the work of Lefebvre stems from the fact that his work demonstrates how the production of space serves as a power base for certain actions and is principally a means of control and domination that inevitably contributes to exclude some citizens to the advantage of others (Soja, 1996).

In this paper we understand migrant organisations where refugee and migrant women are trying to gain access to paid work as a/topia spaces. As highlighted by Martin (2014) looking at the case of Chicago, organisations where migrant women volunteers work on a daily basis are 'spaces of hidden labour'. Their invisibility lies in the fact that migrant women's work as volunteers does not figure in official statistics, it is not valued by funders and to some extent only employers directly benefit from it. Given the resonance of this fact with decades of feminist debate about private versus public space as respectively feminine and masculine spaces (Barrett and Phillips, 1992; Landes, 1998; McDowell, 1983, 1999; Moller-Okin,1998; Rose, 1993; Spain, 1992; Terlinden, 2003; Vacchelli, 2008; Watson, 2002), adding a specific definition such as 'a/topia' to illustrate the lack of access to the public space for migrant women working in the voluntary and community sector seems particularly appropriate in order to gender the debate on space appropriation in the neoliberal city.

\section{Migrant women volunteering in third sector organisations: a crisis of social reproduction?}


The volunteer work of migrant and refugee women in community organisations, that we explore in the context of London can also be inscribed in the broader debate of the current crisis of social reproduction (Brown et al., 2013; Kofman, 2012; Martin, 2010, 2014) where gaps in reproductive labour have been created in the last few decades by a combination of parallel processes that have involved changes in the way family and work-life balance are organised and women's increased mobility in the workforce (Truong, 1996; Kofman, 2012). In this context, the changes in reproductive labour of wealthier professional women have in turn shaped the ability for different categories of migrants to reproduce their own families and have created an increased interdependence between the social reproduction needs of global middle class women and usually racialized, poorer migrant women whose ability to migrate as low-skilled migrants is increasingly restricted.

A number of studies looking at the issue of migrant women in the UK have paid particular attention to domestic labour, care work and family migration (Anderson, 2015; Kofman, 2012; Reynolds and Zontini, 2013; Zontini, 2012). Beyond reproductive labour in the household, the private and the volunteer and community sector have been identified as other key sites of social reproduction. The prevalence of women's migrant labour in these sites varies according to different welfare regimes (Kofman and Raghuram, 2015). Migrant women's reproductive activities play an increasing role in the provision of care within European countries' so called 'care-regimes', specifically with regards to childcare and eldercare in both the private and public sector (Da Roit and Weicht, 2013). The key contribution of this paper to the existing literature of social reproduction and women migrant labour is our argument that within the community and voluntary sector in London, reproductive activities are not just directed to the elderly, the child or the disabled but they are forms of solidarity among women that should be reckoned with in terms of theories as well as policy measures.

We understand the space occupied by volunteer migrant women in London according to the concept of a/topia as migrant and refugee women's everyday lives are confined in domesticlike space and are characterised by a lack of physical access and use of urban space given their predominance in (under)paid and unpaid spaces of care. We question how migrant and refugee women working in third sector organisations, from an uncertain position suspended between paid and unpaid work, can gain visibility, voice and access to city resources. Elaborating on topia through the idea of appropriation of urban space in relation to volunteering expands our understanding of home-making and bottom-up civic participation in the city.

As we could ascertain from our experience of researching on women's organisations London, migrant and refugee women working in third sector organisations often seek integration into the labour market from the marginalised position of unpaid volunteering. This is also found in Martin's work in Chicago (2014) where she defines non-profit organizations as serving the 
purpose of bridging across the different spheres- that of social reproduction and that of the labour market which migrant women are trying to access. 'Crisis of social reproduction' is therefore understood as a conundrum whereby on the one hand third sector organizations provide a set of valuable opportunities for migrant and refugee women to integrate, on the other hand the kind of social-reproduction work these women do in organizations inevitably reinforces their invisibility and marginalization. Due to deskilling and language barriers migrant volunteers face, volunteering is often situated in continuity with domestic work, it is hidden, unaccounted for, unprotected and little documented. Chances for upward mobility are poor as very often these women carry a disproportionate burden of caring for younger, elderly and sick members of their family and of society. This position contributes to their socio-economic vulnerability.

\section{Migrant and women's organisations as drivers for integration}

As evident from the contentious Casey Review (2016), a government-sponsored report on integration, migrant women are at the centre of debates on failed integration in the UK. Another recent report (EAVES, 2015) highlights that migrant women on spousal visas have a high propensity to work in part-time, be deskilled and/or work in the volunteering sector. Volunteering is often perceived as an opportunity for these women who face a number of barriers to integration and notably in integrating in the labour market.

However, with little research and estimations of the number of women engaged in the voluntary and community sector, we endeavour a scoping examination of the hidden labour of migrant women in London by using Tomlinson and Erel (2005)'s research on the trajectories of refugee women working as volunteers in third sector organisations. This work seeks to expand the official definition of volunteering beyond its formal understandings as limited to formalised organisation settings to encompass informal, community-based volunteering. Like Lukka and Ellis (2001), they suggest that BME (Black and Minority Ethnic) communities are more likely to take part in informal, non-organisational based volunteering. Their analysis of policy documents points to the fact that there is a distinction between the BME sector and the mainstream or wider voluntary sector, whereas the former is based on self-help and the latter on the benevolent involvement of middle-class volunteers (Home Office 2000 quoted in Tomlinson and Erel, 2005).

Tomlinson and Erel (2005)'s research points to the fact that volunteering should be highlighted in refugee resettlement policies and given more support not just as a tool for refugee and migrant integration; migrant and refugee women should be seen as actively shaping and improving society. This view represents our starting point which we argue by using a gendered right to the city framework of inquiry. This is done by firstly looking at the 
ways in which current policy discourses and practice seek to impose a top-down idea of civic participation, where the role of migrant groups and organisations can only be valued in the context of an active civil society able to replace the vacuum left by the progressive erosion of the welfare state. Secondly, by looking at how bottom-up civic participation looks like for migrant women volunteering in third sector organisations.

\section{1) Top-down civic participation and the role of migrant organisations}

The policy discourse in the UK posits that migrant organisations play the important role of promoting civic participation for migrants at a local level. A report by Gidley and Jayaweera (2010) examines the Mayor's integration strategy [at the time of the then Conservative mayor of London Boris Johnson] and argues that migrant communities are key actors for promoting economic, civic, social and cultural integration. According to this strategy, the promotion of civic activities at a local level through the active involvement of community groups is core to successful migrant integration. A range of community development strategies mix a bottomup with a top-down approach to civic participation of migrants, highlighting how the work of migrant and refugee communities themselves develops alongside with the work of more mainstream and privatised development providers. Community development is promoted directly via local structures of governance and via the voluntary and community sector.

Evidence shows that the site for migrant's civic participation is the local level where a number of stakeholders including local authorities, voluntary and community sector and locally embedded community development organisations, trade unions, employers have the ability to offer migrant integration.

In this governmental strategy, the about 500 migrant and refugee community organisations in London appear as key social actors. They are considered important because of a range of reasons including 'the great diversity they offer', as well as providing 'a platform for articulating specific interests of migrants, and as the stepping stone to wider civic participation' (Gidley and Jayaweera, 2010, 77). Migrant organisations offer a specific kind 'social capital of organisations' (Tillie, 2004) which is functional to migrants' integration (Schrover and Vermeulen, 2005). Despite the central role recognised to migrant organisations by the 2010 Mayoral strategy for integration, the report highlights that at policy level low skilled workers, along with family migrants, irregular migrants and students are among the most neglected groups of migrants (Gidley and Jayaweera, 2010,11). We add that these are areas where women are most represented.

Migrant and refugee community organisations often fall 'below the radar', operating with very little funding, unable to access finance' (Gidley and Jayaweera, 2010, 77) as only few are core funded and many are struggling with governance procedures especially where 
irregular migrant are involved. These precarious conditions are coupled with issues inherent to the hidden labour of migrant women in community organisations as it is in other sectors of the informal economy. Community organisations have been read as integral to the functioning of the informal economy because the wide range of programmes and services they provide are essential to the social reproduction of migrant workers (Kofman and Raghuram, 2015, Martin, 2010).

We suggest that the discourse on migrant communities as drivers of migrant integration presents some caveats and that it must be inscribed in the political-economic context of volunteering in relation to the neo-liberal state and urban governance in the UK. At the level of urban governance, there is a continued effort to encourage volunteering with a particular emphasis on the local scale. These current priorities are of course to be inscribed in a broader governmental neo-liberal strategy disguising an on-going withdrawal of the state in provisions of welfare (Fyfe and Milligan, 2003) and for a while officially recognised as the Big Society. Although no longer part of the government's policy agenda, the ideas of the Big Society and its impetus are alive in a persisting emphasis on volunteering as a way to welfare. These strategies have taken different forms over the years from the 'active citizenship' of the late 1980s- early 1990s, which were to be relayed by the neo-communitarian policies of the 'third way' during Blairite years (Fyfe and Milligan, 2003, 402; Marinetto, 2003, 114-115). 'Active citizenship' was promoted by Thatcherite conservative governments in an effort to reform and restructure the welfare state (Kearns, 1995, 1992, 20). In many ways, New Labour pursued this 'neo-liberal hegemonic project' and this is most exemplified as Davies (2012) argues 'in the social sphere and the politics of active citizenship' (Davies, 2012, 3). The 'citizen-volunteer' as one aspect of these politics continues to be central to the Tories' 'social justice' project in the Cameron years and in Theresa May's recent 'shared society idea' (Singh, 2017).

We argue that 'civic participation' needs to be understood in a way that takes into consideration relational aspects highlighted in Askins (2016) not as to 'encourage' citizenship within a 'hegemonic project' (Davies, 2012). In doing so, we shift our focus on the kind of agency and resiliency strategies enacted by migrant women working in migrant organisations. We are particularly interested in the role played by migrant women through volunteering activities in community organisations that notably adopt unconventional approaches to what we understand as bottom-up, people driven civic participation and is different from the topdown, policy driven idea of civic integration explored in this section.

\section{2) Practicing the right to the city: transforming the city from below}

The invisible spaces of third sector organisations working with women, migrants and refugees and their role in facing the crisis of social reproduction are often neglected in policy 
and academic discourses alike. In this final section, we aim to offer a brief overview of the work of one specific organisation as a way of reflecting on what kind of social relations are produced in the hidden and temporary/transient spaces of volunteering.

Care work as the kind of work practiced in migrant organisations to help women to break from isolation is often led by migrant volunteers who in turn have benefitted from the help they received from other migrant volunteers. This kind of solidarity work has the potential to transform alienating individual experiences into collective understandings of social structures, racial hierarchies and forms of economic exploitation. An examination of organisational practices and people working in BME women's organisation in London suggests that organisations have the ability to transform social reproduction challenges into bottom-up approaches to community integration.

As an example of an organisation engaging with relational bottom-up approaches, we expand here on the work done by the organisation MEWso (Middle Eastern Women support organisation $)^{2}$ in North London. MEWso helps Middle Eastern women to break out from isolation, guide them out from the confinement of the home and make them feel more integrated in the community. The organisation relies on 17-18 community based volunteer most of whom share the same cultural and migration background of the women they help; others are with white British women who devote some of their time for this cause. At MEWso, the shadowy world of social reproduction and day-to-day care for the socially excluded and marginalised is based on the unpaid volunteer work of both migrant and white British women who offer their time to help migrant women integrate and feel part of the British society starting from the communities they live in.

MEWso deploys solidarity-based ways to break the isolation of many migrant women. These activities range from health workshops, group meditation, holistic massage, dance therapy classes, classes for self-esteem, parenting workshops, gardening and other group sports activities (such as cycling and swimming) to one-to one counselling. Sometimes this involves organising events in the communities and workshops on advocacy in welfare. Other activities include support in physical and mental health and range from emotional support to counselling, signposting and accompanying women in need to the GP to help with language barriers. MEWso's founding director recounts:

Especially when you are a refugee you are weak depressed and cannot manage the language, if somebody is with you this changes.

\footnotetext{
${ }^{2} \mathrm{We}$ reflected on the ethical tension existing between maintaining anonymity and providing the name of the organisation. As we would like to recognise the work of MEWso, we contacted the organisation, asked for permission to name the organisation and provided a draft copy of this paper. The director gave her consent to be named and expressed her excitement for this publication.
} 
Speaking about one of the dance therapy sessions she explains:

'In particular during the dance therapy sessions they identify a pain in their body and then everyone is getting a massage in the same position for solidarity. This is a way to start talking about themselves, they share their cultural music and at the end they are just laughing. This is the whole meaning of it, feel happier and then when they come to sit in the ring for meditation they discuss it and say if they have enjoyed it or not. That is amazing I used to be there at every session.

Some of these initiatives have been challenging for the organisation. The founder of MEWso relates that for instance in the parenting workshops some women could not discuss family issues with the broader group and the women tended to ask for help after the group on a oneto-one basis. Cultural barriers and power relations within a group of people can prevent disclosure when activities are led in a group where participants already know each other. Women's organisations are very sensitive to cultural issues and are constantly developing ways to overcome barriers and find alternative approaches to provide customised support to the women they help.

In the opinion of the funder of MEWso, building solidarity is more important than the kind of services provided by any one organisation- this is at least her ethos that really emphasises the importance of solidarity. She told us that she is very sceptical about integration in the larger society, this is 'a big slogan' and she firmly believes in a kind of 'integration' that happens in small steps, 'in small groups in the neighbourhood so that they can feel the benefits for it' 'they are more empowered and they cannot go from isolation to the broader English society'. Grass root women's organisations like MEWso are working towards developing bottom-up participation through solidarity oriented practices. This is central to the gendered right to the city, at a time when citizenship is becoming a more and more central factor in determining the eligibility of services and top-down agendas of active citizenship are being imposed through governance discourses and practices.

Martin's point that 'social reproduction is being reframed as a collective endeavour within organizations, where the ethic of care is potentially transforming an insidious politicaleconomic context into a source of strength and resiliency for migrant women' (Martin, 2014, 17) is useful to understand the work of MEWso as well as other similar support organisations. Appropriation of a civic space through relational and solidarity practices as exemplified in the work on the ground carried out by MEWso should represent a way to situate social reproduction, or a/topia as we conceptualised it in this article, into a recognised public sphere (topia) taking place at a local level in small organisations. The everyday activities promoted by MEWso play an important role in fostering bottom-up social integration of Middle Eastern women in North London. By meeting other people, receiving help in accessing health and other services, sharing music, food and dance Middle Eastern migrants develop a sense of 
belonging to a local community away from the isolation of their own homes and start inhabiting the city as active and 'resilient' (DeVerteuil, 2015) citizens.

Women's and migrants' organisations are faced with increasing challenges in the current political climate. On the one hand, more than ever before, their role of mediating social, political and economic needs of migrants is required given the increased burden on community organisations at a time of retrenchment of centralised funding for services. On the other hand, organisations themselves have been severely curtailed by current neoliberal and austerity geared economic politics (for an in depth discussion of this aspect see Vacchelli et al. 2015). These policies have a distinct spatial dimension as demonstrated by the current debates on austerity and localism (Vacchelli, 2015).

\section{Conclusion}

This paper has looked at the role of migrant organisations both as places of co-option of migrant labour, as places that enable the integration of migrants and make their participation in the urban fabrics possible, and as places that are appropriated by migrant volunteers in London as a means of enacting active citizenship. The invisibility of migrant and refugee women's labour in third sector organisations is reinforced by current policy discourses imposing a top-down model of active citizenship which sits at odds with structural aspects of neo-liberalism and the material experiences of women seeking to belong and participate as migrants in the public sphere.

Lefebvre's theoretical framework of 'space appropriation' served as a way to explore these contradictory questions and we proposed a further spatial reading which is specific to a gendered right to the city, i.e. the shift from a/topia (not having a space or being denied access to public spaces broadly conceived) to topia. Volunteer work in women and migrant organisations is practiced from a relatively invisible position situated in continuity with the domestic sphere. However volunteering as form of civic participation is a useful strategy for integrating at the level of the individual and of the local community. Migrant women are caught in a tension whereby on the one hand they are offered an opportunity to access the labour market (though from a marginalised position) through volunteering in third-sector organisations. On the other hand, mainly due to deskilling and language barriers, they fall back on social reproduction roles. These circumstances makes it difficult to attain upwards social mobility, yet civic participation from below represents a way to enact forms of resistance through solidarity that effectively represent space appropriation in Lefebvrian terms of the right to the city. 
As briefly exemplified by the work of the organisation MEWso, isolated and hard to reach migrant women are helped by volunteers through creative self-help, body work and a combination of emotional and practical support. Here, social reproduction routine activities stop being individual and open up towards more collective, solidarity-driven relational practices, situated outside a merely domestic domain (where the discourse about women is too often confined).

We discussed this newly appropriated sphere as a topia, a public space that allows volunteers to enact bottom-up civic participation starting from solidarity practices of mutual support. This contributes to configure the 'gendered' right to the city as breaking the dichotomy of public and private, where migrant and refugee women are seen as actively shaping and improving society and equally participating in the creation of urban spaces. This perspective is particularly important at a time of rising social inequalities affecting women, refugee and migrant's organisations with greater propensity. Similarly, most migrant women who work as volunteer in third sector organisations are situated at the intersection of non-hegemonic ethnicities and weak socio-economic status and are therefore disadvantaged and made invisible. Volunteering in this specific instance, as demonstrated in this paper represents an opportunity to enact forms of solidarity through daily practices that involve the use of the body, affect and mutual care. The kind of space appropriation that happens through volunteering in third sector organisations is situated in continuity with the private sphere where care and forms of mutual solidarity are used as a starting point to claim a specifically gendered right to the city.

\section{$\underline{\text { References }}$}

Anderson, B (2015) Migrant Domestic Workers: good workers, poor slaves, new connections, social politics: international studies. Gender, State and Society 22 (4), 636-652.

Askins, K (2016) Emotional citizenry: everyday geographies of befriending, belonging and intercultural encounter. Transactions of the Institute of British Geographers, 41(4), 515-527.

Barrett, M and Phillips, A (Eds) (1992) Destabilizing theory. Contemporary feminist debates. Oxford: Polity Press.

Brown, G, Dowling, E, Harvie, D, and Milburn, K (2013) Careless Talk: social reproduction and fault lines of the crisis in the United Kingdom. Social Justice 39 (1) (127), 78-98. 
Buckingham, S (2010) Examining the Right to the City from a Gender Perspective. Cities for All, 57.

Casey, L. (2016) The Casey Review: a report into opportunity and integration available at https:/www.gov.uk/government/uploads/system/uploads/attachment data/file/575973/The C asey_Review_Report.pdf (last accessed 29-01-17).

Da Roit, B and Weicht, B (2013) Migrant Care Work and Care, Migration and Employment Regimes: a fuzzy-set analysis. Journal of European Social Policy 23 (5), 469-486.

Davies, JS (2012) Active Citizenship: navigating the Conservative heartlands of the New Labour project. Policy and Politics 40 (1), 3-19.

DeVerteuil, G (2015). Resilience in the post-welfare inner city: voluntary sector geographies in London, Los Angeles and Sydney. Policy Press.

Doderer, YP (2003) Urbane Praktiken. Strategien und Raumproduktionen feministischer Frauenoffentlichket, Muenster: Verlaghaus Monsenstein und Vannerdat.

EAVES (2015) Settling In: experiences of women on spousal visas in the UK available at http://www.fawcettsociety.org.uk/wp-content/uploads/2015/06/Settling-In-research-report9795c1.pdf (Last accessed on 09-05-2016).

Fenster, T (2005) The right to the gendered city: different formations of belonging in everyday life'. Journal of Gender Studies 14 (3), 217-231.

Fyfe, NR and Milligan, C (2003) Out of the Shadows: exploring contemporary geographies of voluntarism. Progress in Human Geography 27 (4), 397-413.

Gidley, B and Jayaweera, H (2010) An Evidence Base on Migration and Integration in London, ESRC Centre on Migration, Policy and Society, University of Oxford at https://www.london.gov.uk/sites/default/files/an_evidence_base_on_migration_and_integrati on_in_london.pdf (last accessed 25th January, 2016)

Harvey, D (2012) Rebel cities: From the right to the city to the urban revolution. Verso Books.

Kearns, A (1995) Active Citizenship and Local Governance: political and geographical dimensions. Political Geography 14 (2), 155-175.

Kearns, A (1992) Active Citizenship and Urban Governance. Transactions of the Institute of British Geographers 17 (1), 20-34. 
Kofman, E (2012) Rethinking Care through Social Reproduction: articulating circuits of migration. Social Politics 19 (1), 142-162.

Kofman, E, and Raghuram, P (2015) Gendered migrations and global social reproduction. London: Palgrave Macmillan.

Landes, J (Ed) (1998) Feminism, the public and the private. New York: Oxford readings in feminism. Oxford University Press.

Lefebvre, H (1968) Le droit à la ville, Anthopos: Paris

Lefebvre, H (1991) The production of space, translated by Nicholson-Smith D. Oxford: Blackwell

Lukka, P and Ellis, A (2001) An exclusive construct? Exploring different cultural concepts of volunteering. Voluntary Action 3 (3), 87-109.

Marinetto, M (2003) Who wants to be an Active Citizen? The Politics and Practice of Community Involvement. Sociology 37(1), 103-120.

Martin, N (2010) The Crisis of Social Reproduction among Migrant Workers: Interrogating the Role of Migrant Civil Society. Antipode 42 (1), 127-151.

Martin, N (2014) Spaces of hidden labor: migrant women and work in non-profit organization. Gender, Place and Culture: A journal of Feminist Geography 21(1), 17-34.

Marston, SA and Smith, N (2001) States, scales and households: limits to scale thinking? A reponse to Brenner. Progress in Human Geography 25(4), 615-619.

McDowell, L (1983) Towards an Understanding of the Gender Division of Urban Space. Environment Planning D: Society and Space 1, 59-72.

McDowell, L (1999) Gender, identity and place. Understanding feminist geographies. Cambridge, Oxford: Polity.

Moller-Okin, S (Ed) (1998) Gender, the public, and the private. New York: Oxford readings in feminism. Oxford University Press.

Purcell, M (2002) Excavating Lefebvre: the right to the city and its urban politics of the inhabitant. GeoJournal 58, 99-108

Reynolds, T and Zontini E (2013) Care flows in Transnational Families: Cultural and Social Capitals, Identity and Belonging. In Baldassar, L. and Merla, , (eds), Transnational Families, Migration and Kin-work: From Care Chains to Care Circulation, London: Routledge, 
Rose, G (1993) Feminism and geography: The limits of geographical knowledge. Minneapolis: University of Minnesota Press.

Shrover, M and Vermeulen, F (2005) Immigrant Organisations. Journal of Ethnic and Migration Studies 31 (5), 823-832.

Simonsen, K (2005) Bodies, sensations, space and time: The contribution from Henri Lefebvre. Geografiska Annaler: Series B, Human Geography 87(1), 1-14.

Singh, A (2017) 'Theresa May's shared society is not doomed...yet', The Guardian, January 2017 available at https://www.theguardian.com/voluntary-sectornetwork/2017/jan/18/theresa-may-shared-society-acevo-charity (last accessed 10th February 2017)

Soja, E (1996) Third space: journeys to Los Angeles and other real and imagined places Oxford: Blackwell

Spain, D (1992) Gendered spaces. Chapel Hill: University of North Carolina Pres Terlinden, U (Ed) (2003) City and gender. International Discourse on gender, urbanism and architecture. Hemsbach: Leske+Budrich.

Tomlinson, F, and Erel, U (2005) Refugee women: from volunteers to employees. Voluntary action. London Institute for Volunteering Research 7(1), 27.

Tillie, J (2004) Social Capital of Organisations and their members: Explaining the Political Integration of Immigrants in Amsterdam. Journal of Ethnic and Migration Studies 20 (3), $529-541$.

Truong, T-D (1996) Gender, international migration and social reproduction: implications for theory, policy, research and networking. Asian and Pacific Migration Journal 5(1), 47

Vacchelli, E (2008) 'Milan 1970-1980: women's place in urban theory' Research in Urban Sociology. Special edition theme issue: Gender in an Urban World. Vol.9, 29-51

Vacchelli, E (2014) 'Gender and the city: intergenerational spatial practices and women's collective action in Milan' Les Cahiers du Cedref special edition theme issue: 'Le tournant spatial dans les études genre', Vol.21 
Vacchelli, E (2015) 'Localism and austerity: a gender perspective' Soundings no.60, Summer.

Vacchelli, E, Kathrecha, P, Gyte, N (2015) 'Is it really just the cuts? Neoliberal tales from the women's voluntary and community sector in London' Feminist Review 109, 180-189

Watson, S (2002) City A/Genders" in Bridge, G and Watson, S (eds) Blackwell city reader. Oxford: Blackwell.

Yuval-Davis, N (2007) "Intersectionality, Citizenship and Contemporary Politics of

Belonging" in Bennett, J (ed) Scratching the Surface: democracy, traditions, gender, Lahore:

Heinrich Boll Foundation, 7-22

Yuval-Davis, N (1999) 'The 'Multi-layered Citizen'. International Feminist Journal of Politics 1 (1). 119-136.

Zontini, E (2012) Care arrangements of elderly transnational migrants: between family, community and the state. In Weller, S and Rogers, C (eds), Critical Approaches to Care: Understanding Caring Relations, Identities and Cultures London: Routledge. 
From a/topia to topia: towards a gendered right to the city for migrant volunteers in London

\section{HIGHLIGHTS}

An analysis of migrant women's volunteer work in London is proposed

Their position of invisibility makes it difficult to achieve social mobility and participate in the public sphere as citizens

$>$ Policy discourses impose top-down model of active citizenship which sits at odds with the material experiences of migrant women who volunteer in the VC sector

We understand topia, a public space that allows volunteers to enact bottom-up civic participation starting from solidarity practices of mutual support

Civic participation from below represents a way to enact forms of resistance through solidarity i.e. space appropriation in Lefebvrian terms of the right to the city 
Title: "From a/topia to topia: towards a gendered right to the city for migrant volunteers in London"

\section{Authors' information:}

Dr. Elena Vacchelli, Senior Lecturer in Sociology

Department of Criminology and Sociology

Social Policy Research Centre

www.sprc.info

Middlesex University

The Burroughs

London NW4 4BT

Dr Magali Peyrefitte, Lecturer in Sociology

Department of Criminology and Sociology

Middlesex University

The Burroughs

London NW4 4BT 